UDK: 343.4:331(497.11)

doi: $10.5937 /$ crimen2102167S

PREGLEDNI ČLANAK

PRIMLJEN / PRIHVAĆEN: 20.05.2021. / 27.09.2021.

\title{
Aleksandar Stevanovic*
}

Institut za kriminološka i sociološka istraživanja

\section{KRIVIČNO DELO POVREDE PRAVA PO OSNOVU RADA I PRAVA IZ SOCIJALNOG OSIGURANJA: PROBLEMI U PRAKSI I POTREBA ZA NOVELIRANJEM}

\begin{abstract}
Apstrakt: Autor nastoji da razmotri opšte karakteristike krivičnog dela Povreda prava po osnovu rada $i$ prava iz socijalnog osiguranja koje je propisano članom $163 \mathrm{KZ}$. To čini iz razloga što je u praksi postupanja organa formalne socijalne kontrole u pogledu primene krivične norme kojom je propisano predmetno krivično delo, prisutna neujednačenost $\mathrm{u}$ smislu pravne kvalifikacije povreda prava kojima se konkretnom inkriminacijom pruža zaštita. Praktični problemi za koje je autor nastojao da ponudi rešenje ogledaju se u povredi principa zabrane dvostruke kažnjivosti (ne bis in idem), do čega dolazi kada se za povredu prava iz istog činjeničnog osnova, paralelno ili konsekventno goni prema pravilima prekršajnog i krivičnog postupka. Pored ukazivanja na bitne karakteristike analiziranog krivičnog dela, autor je razmotrio i kriminalno-politički aspekt predmetne inkriminacije, kao bi se na valjan način utvrdilo njeno mesto i cilj u okviru kaznenog sistema. Konačno, u radu su razmotrena i određena de lege ferenda rešenja sa ciljem da se ukaže na moguće pravce noveliranja krivičnog zakonodavstva kada je reč o zaštiti prava radnika.
\end{abstract}

Ključne reči: rad, prava po osnovu rada, ne bis in idem, krivična zaštita radnika.

\section{UVOD}

Inkriminisanje dela protiv radnih odnosa opravdana je težnja zakonodavca da pruži zaštitu radu kao društveno-ekonomskoj kategoriji od vitalnog značaja za funkcionisanje svake države. Potreba za krivičnopravnom zaštitom prava po osnovu rada kod nas je prvi put prepoznata sa donošenjem Krivičnog zakonika iz 1951. godine kada su dela protiv radnih odnosa implementirana u krivično zakonodavstvo i sistematizovana u posebnu glavu Zakonika, ${ }^{1}$ čime je naglašen njihov značaj za sistem političkih, proizvodnih i socijalnih odnosa u društvu.

aleksandar.stevanovic993@gmail.com. Tekst je nastao kao rezultat rada na projektu „Kriminal u Srbiji: fenomenologija, rizici i mogućnost socijalne intervencije“ (br. 47011) finansiran od strane Ministarstva prosvete, nauke i tehnološkog razvoja Republike Srbije.

1 Z. Stojanović, N. Delić /2013/: Krivično pravo - posebni deo, Beograd, p. 62. 
Normativnoj unifikaciji radnog prava u značajnoj meri su doprinele aktivnosti međunarodnih organizacija i tela, među kojima se po logici stvari izdvaja Međunarodna organizacija rada - MOR. Ipak, kvalitet radnih odnosa u osnovi zavisi od spremnosti političkih aktera da omoguće efikasnu primenu radnih, socijalnih, poreskih, privrednih i uopšte propisa koji neposredno ili posredno uokviruju radne odnose. Važnu komponentu u tom zaštitnom mehanizmu nesumnjivo pruža i krivično zakonodavstvo koje se po pravilu javlja kao ultima ratio korektiv.

Pojedine radnje i propuštanja su protekom vremena i radnopravnim emancipovanjem društva postale opšta mesta kada je reč o pružanju zaštite u oblasti radnih odnosa. Otuda, kada je reč o normativnom okviru MOR-a, četiri fundamentalne vrednosti koje proizilaze iz nekoliko osnovnih konvencija koje se tiču zaštite osnovnih ljudskih prava na radu su se izdvojile, težeći postizanju konsenzusa među „socijalnim partnerima” o tome koja prava bi trebalo smatrati „osnovnim” i usled toga im pružiti posebnu zaštitu. ${ }^{2}$ Krajem prošlog milenijuma, u okviru MOR-a je usvojena „Deklaracija o osnovnim principima i pravima na radu”, u kojoj se naročito ukazuje na značaj: slobode udruživanja i efektivno priznavanje prava na kolektivno pregovaranje; eliminisanja svih oblika prisilnog ili obaveznog rada; efikasnog ukidanja dečijeg rada i uklanjanja diskriminacije u pogledu zaposlenja i izbora zanimanja.

Domaće krivično zakonodavstvo prepoznaje značaj navedenih prava tako što im pruža zaštitu u vidu posebnih (specijalnih) inkriminacija, ${ }^{3}$ dok propisivanje krivičnog dela Povreda prava po osnovu rada i prava iz socijalnog osiguranja ima cilj da na opšti način zaštiti sistem radnih odnosa u celini. Upravo je „opštost” u pružanju zaštite, iako opravdana sa društveno-političkog stanovišta, čest koren problema koji nastaju u sudskoj praksi prilikom tumačenja i primene navedene norme. Oni se na prvi pogled mogu podeliti na poteškoće u uspostavljanju efikasne kaznene politike u oblasti zaštite prava radnika, kao i na pitanje odgovarajuće primene principa ne bis in idem u kaznenom pravu.

\section{OSNOVNE KARAKTERISTIKE KRIVIČNOG DELA POVREDE PRAVA PO OSNOVU RADA I PRAVA IZ SOCIJALNOG OSIGURANJA}

Sa gledišta kaznene politike, krivično delo predviđeno čl. 163 Krivičnog zakonika (u daljem tekstu: $\mathrm{KZ}$ ) 4 štiti sistem radnih odnosa tako što inkriminiše samo nepridržavanje relevantnih zakona, podzakonskih akata, kolektivnih ugovora i drugih opštih akata, uz dodatni kvalifikativ (posledica krivičnog dela) prema kojem je za ostvarivanje bića dela neophodno da to nepridržavanje dovede do uskraćivanja ili ograničavanja radnih i socijalnih prava koja pripadaju pasivnom subjektu krivič-

2 J. R. Bellace /2014/: Human Rights at Work: The Need for Definitional Coherence in the Glob Governance System, The International Journal of Comparative Labour Law and Industrial Relations, vol. 30, $\mathrm{n}^{\mathrm{o}} 2$, p. 178.

3 Primera radi: Sprečavanje političkog, sindikalnog i drugog udruživanja i delovanja, Zloupotreba prava na štrajk, Rasna i druga diskriminacija, Trgovina ljudima.

4 Službeni glasnik RS, br. 85/2005, 88/2005 - ispr., 107/2005 - ispr., 72/2009, 111/2009, 121/2012, 104/2013, 108/2014, 94/2016 i 35/2019. 
nog dela - oštećenom. Kvalitet i obim tog nepridržavanja nisu predviđeni, što prouzrokuje brojne nedoumice u pogledu primene odredbe čl. $163 \mathrm{KZ}$ na konkretne povrede radnih i socijalnih prava.

Blanketni karakter krivičnog dela upućuje na primenu i radnopravnih i socijalnopravnih zakonskih i podzakonskih akata, kao i propisa autonomne prirode (pravilnici o radu, kolektivni ugovori) koji normiraju prava po osnovu rada. Pored toga, važno je imati u vidu i da ta prava kojima se pruža krivičnopravna zaštita, variraju i zavise od režima u kojem se rad obavlja. Sledstveno tome, pored opšteg režima oličenog u Zakonu o radu (u daljem tekstu: ZOR) ${ }^{5}$ postoje i posebni, čija je sadržina predviđena različitim propisima u zavisnosti od konkretne oblasti.

Upućujuća priroda analiziranog dela pretpostavlja valjano poznavanje instituta i pravila koja primarno regulišu društveni odnos kojem se pruža krivičnopravna zaštita kao krajnje sredstvo. U konkretnom slučaju, važno je primetiti da zakonodavac predviđa zaštitu prava po osnovu rada, a ne samo prava iz radnog odnosa, budući da je potonja kategorija uža i nastaje tek po uspostavljanju radnog odnosa koji naš zakonodavac nije definisao, ali posredno pravi jasnu razliku između rada koji se obavlja u okviru radnog odnosa i onog koji se obavlja izvan njega. Praktičan značaj ove napomene ogleda se u činjenici da se kao oštećena krivičnim delom mogu pojaviti i lica koja obavljaju rad na osnovu ugovora kojima se ne zasniva radni odnos. ${ }^{6}$

Kako se krivičnom odredbom koju analiziramo propisuje kazna za povredu prava po osnovu rada, proizlazi da zonom predmetne inkriminacije nisu obuhvaćeni pojedini segmenti povrede prava na rad kao šire kategorije, a koje članom 60, stavom 2-3 jemči Ustav RS. ${ }^{7}$ Naime, norma kojom je propisano razmatrano krivično delo ne bi se mogla primeniti na povrede zakona i kršenja prava koja se odnose na izbor zanimanja i zapošljavanje, jer u tom trenutku još uvek nisu konstituisana prava po osnovu rada za konkretno lice koje trpi povrede.

Kada je reč o zaštiti prava iz socijalnog osiguranja, stvari su donekle jednostavnije. Kažnjiva je povreda prava iz socijalnog osiguranja koja imaju zaposleni, radno angažovani, ${ }^{8}$ ali i članovi njihovih porodica.

Konačno, zaštita se pruža kako individualnim, tako i kolektivnim pravima po osnovu rada. To nesumnjivo proističe iz sistema radnog zakonodavstva koje štiti osnovna individualna prava kao što su pravo na naknadu za rad ili pravo na godišnji odmor, kao i kolektivna prava kakva su pravo na udruživanje ili pravo na kolektivno pregovaranje ili pravo na štrajk.

Službeni glasnik RS, br. 24/2005, 61/2005, 54/2009, 32/2013, 75/2014, 13/2017 - odluka US, 113/2017 i 95/2018 - autentično tumačenje.

6 To su kod nas ugovor o obavljanju privremenih i povremenih poslova, ugovor o delu i ugovor o stručnom usavršavanju i osposobljavanju.

7 Službeni glasnik RS, br. 98/2006.

8 Vid. recimo čl. 7, st. 1, tač. 3 Zakona o doprinosima za obavezno socijalno osiguranje (Službeni glasnik RS, br. 84/2004, 61/2005, 62/2006, 5/2009, 52/2011, 101/2011, 7/2012 - usklađeni din. izn., 8/2013 - usklađeni din. izn., 47/2013, 108/2013, 6/2014 - usklađeni din. izn., 57/2014, 68/2014 - dr. zakon, 5/2015 - usklađeni din. izn., 112/2015, 5/2016 - usklađeni din. izn., 7/2017 - usklađeni din. izn., 113/2017, 7/2018 - usklađeni din. izn., 95/2018, 4/2019 - usklađeni din. izn., 86/2019, 5/2020 - usklađeni din. izn., 153/2020 i 6/2021 - usklađeni din. izn.). 
Radnja krivičnog dela je nepridržavanje nabrojanih pravnih akata i predviđena je tako da se može izvršiti i činjenjem i nečinjenjem. U prvom slučaju se radi o postupanju protivno pozitivnim propisima, dok je u potonjem reč o neprimenjivanju tih propisa. ${ }^{9}$ Relevantan oblik krivice je umišljaj, što proizlazi iz činjenice da je za postojanje krivičnog dela i utvrđivanje krivične odgovornosti neophodno svesno nepridržavanje propisa. ${ }^{10}$ Valja imati u vidu da svest o nepridržavanju propisa ipak nije isto što i umišljaj učinioca, kada je reč o krivičnom delu Povrede prava po osnovu rada i prava iz socijalnog osiguranja. ${ }^{11}$ Taj zaključak izvodimo iz pravila da i posledica krivičnog dela ukoliko je predviđena, kao što je to slučaj kod predmetnog, mora biti obuhvaćena umišljajem učinioca. Umišljaj potencijalnog izvršioca morao bi da obuhvati i posledicu krivičnog dela - uskraćivanje ili ograničavanje prava. Konačno, svesno nepridržavanje propisa podrazumeva i „nesumnjivost” prava koje se povređuje.

Sudska praksa nameće još jednu okolnost koju možemo označiti kao „kvazi uslov kažnjivosti”. Radi se o činjenici da za krivično delo neće odgovarati lice koje krši prava po osnovu rada onda kada ne postoje objektivne mogućnosti da se ona ostvare. ${ }^{12}$ Tu se praktično osporava stav da poslodavac koji u dužem vremenskom periodu posluje sa gubicima, nužno ne isplaćuje zaradu zaposlenima kako bi im uskratio ili ograničio prava na zaradu. Da bi se „nepostojanje objektivnih mogućnosti" moglo utvrditi u svakom konkretnom slučaju, potrebno je razviti kriterijume na osnovu kojih bi se vršila procena negativne ekonomske situacije poslodavca, koja je po pravilu izvorište objektivne nemogućnosti da radnici ostvare svoja prava, pa tako i nepridržavanja propisa od strane poslodavca. ${ }^{13}$

Fleksibilan zakonski opis konkretne inkriminacije ostavlja mogućnost da se utvrdi krivična odgovornost poslodavca koji povređuje prava radnika i onda kada se on objektivno gledano nalazi u negativnoj ekonomskoj situaciji. Poslodavac se i u takvim okolnostima svesno ne pridržava propisa, a njegov umišljaj po pravilu obuhvata uskraćivanje ili ograničavanje prava radnika, $s$ tim da je njegova namera usmerena ka opstanku preduzeća. Zato bi u postojeći zakonski opis trebalo uvesti i nameru, tako da biće dela ostvaruje onaj ko se svesno ne pridržava propisa sa namerom da radniku uskrati ili ograniči određeno pravo. Drugo, adekvatnije rešenje u odnosu na domaći KZ je ono za koje se opredelio zakonodavac u Hrvatskoj kada je propisujući krivično delo Neisplata plaće, ${ }^{14}$ predvideo da nema krivičnog dela ukoliko je do neisplate došlo zbog nemogućnosti raspolaganja finansijskim sredstvima na računu poslodavca, a što nije uzrokovano s ciljem izbegavanja isplate. Čini se da ovakvo rešenje najviše pogoduje zahtevima zakonitosti u krivičnom pravu.

9 D. Atanacković /1981/: Krivično pravo - posebni deo, treće izdanje, Privredna štampa, Beograd, p. 217.

10 Teško bi se moglo očekivati da je predmetno krivično delo moguće izvršiti sa svesnim nehatom.

11 D. Atanacković: op. cit., p. 217.

12 Presuda OS u Subotici Kž. 411/07.

13 Tako se recimo u španskom pravu, može govoriti o negativnoj ekonomskoj situaciji onda kada je tokom tri uzastopna kvartala, nivo redovnih prihoda ili prodaje u svakom kvartalu niži od nivoa prihoda ili prodaje koji je bio zabeležen u istom kvartalu prethodne godine (LJ. Kovačević /2016/: Valjani razlozi za otkaz ugovora o radu, Pravni fakultet Univerziteta u Beogradu, Centar za izdavaštvo i informisanje, Beograd, p. 403).

14 Vid. čl. 132, st. 3 Kaznenog zakona (Narodne novine, br. 125/11, 144/12, 56/15, 61/15, 101/17, 11 8/18, 126/19), koji je na snazi u Republici Hrvatskoj. 
Trenutna situacija u domaćoj sudskoj praksi je takva da su sudovi primorani da fleksibilno tumače umišljaj izvršioca u odnosu na posledicu dela, uzimajući u obzir njegovu nameru, koja pri tom nije predviđena u biću dela. Zato se „objektivna nemogućnost ostvarivanja prava” može označiti kao „kvazi uslov kažnjivosti” budući da kao takva nije deo zakonskog opisa dela, niti je predviđena kao osnov koji isključuje protivpravnost.

U teoriji i sudskoj praksi dominira stav da izvršilac razmatranog krivičnog dela može biti poslodavac ili odgovorno lice kod poslodavca. Polazeći od teze da strane $\mathrm{u}$ radnom odnosu nisu jednake, ${ }^{15}$ odnosno da je poslodavac dominantna strana $\mathrm{u}$ odnosu na radnika, naročito u ekonomskom i organizacionom aspektu, nesporna je tendencija zakonodavca da ovom krivičnom odredbom najpre pruži zaštitu radnicima. Ipak, kako je obavljanje rada u pravnom, ali i sociološko-ekonomskom smislu dvostrani odnos, važno je imati u vidu da prava po osnovu rada, obuhvataju i prava koja upravo po tom osnovu pripadaju i poslodavcu. Dilemu u pogledu pitanja da li izvršilac krivičnog dela propisanog čl. $163 \mathrm{KZ}$ može biti i lice koje obavlja rad, valjalo bi razrešiti uz oslonac na ultima ratio prirodu krivičnog prava i cilj radnog prava kao samostalne grane prava.

Najpre, ultima ratio karakter krivičnog prava nužno ukazuje da nije uvek opravdano koristiti njegove mehanizme za zaštitu onih individualnih i kolektivnih interesa koji mogu biti zaštićeni na drugi, pogodniji način. Kako ono po pravilu podrazumeva najveći stepen prinude, važno je voditi računa o tome da mehanizmi krivičnopravne reakcije budu stavljeni u pogon samo onda kada izostaje adekvatna zaštita „čoveka i drugih osnovnih društvenih vrednosti” 16 drugim, manje represivnim sredstvima. Na taj način se krivičnopravnim normama obezbeđuje neophodni legitimitet koji čini element vladavine prava, naročito u pogledu njihove primene. ${ }^{17}$ Drugo, radno pravo je krajem XIX veka konstituisano kao samostalna grana pra$\mathrm{va}^{18}$ sa sopstvenim i specifičnim predmetnom regulisanja. Pre toga, rad je shvatan kao ugovorna kategorija među jednakim stranama koja se zasniva na osnovnom principu građanskog prava, autonomiji volje. ${ }^{19}$ Naročito je u SAD u periodu pre „Novog dogovora” (New Deal) radni odnos tretiran kao odnos čisto privatnog karaktera dveju strana, bez percepcije da se tu radi o postojanju međusobnih prava i obaveza, ${ }^{20}$ kao i izražene potrebe za državnom intervencijom u polju zaštite osnovnih prava iz tog odnosa. Taj stav je bio prisutan i u sudskoj praksi. ${ }^{21}$

15 O. Kahn-Freund /1972/: Labour and the Law, Stevens\&Sons, London, p. 8

16 Član $3 \mathrm{KZ}$ koji propisuje da:,,zaštita čoveka i drugih osnovnih društvenih vrednosti predstavlja osnov i granice za određivanje krivičnih dela, propisivanje krivičnih sankcija i njihovu primenu, u meri u kojoj je to nužno za suzbijanje tih dela."

17 D. Husak /2008/: Overcriminalization - The Limits of the Criminal Law, Oxford University Press, New York, p. 8.

18 LJ. Kovačević /2013/: Pravna subordinacija u radnom odnosu i njene granice, Pravni fakultet Univerziteta u Beogradu, Centar za izdavaštvo i informisanje, p. 27.

19 Radnopravni propisi su u to vreme bili usmereni na zaštitu interese buržoazije, što Slobodan Jovanović kvalifikuje kao „državnu intervenciju u korist poslodavca.“ (LJ. Kovačević /2013/: Ibid., p. 27).

20 W. C. Summers /1976/: Individual protection against unjust dismissal: Time for a statute, Virginia Law Review, vol. 62, p. 78.

21 Vid. presudu Lochner v. New York, 198 U. S. 45 (1905). 
Vremenom je, na osnovu „stanja na terenu” preovladalo shvatanje da se ugovor o radu zapravo zaključuje između ekonomski nejednakih strana, pa je u tom smislu, zakonodavna intervencija u polju rada, vršena sa ciljem da se zaštiti radnik kao „slabija strana" uz ograničavanje moći i slobode poslodavca. ${ }^{2223}$

Izvršilac dela iz čl. $163 \mathrm{KZ}$ može biti isključivo odgovorno/ovlašćeno lice kod poslodavca, dok se eventualne povrede prava „poslodavačke strane” imaju rešavati na nivou disciplinskog sankcionisanja radnika ili u okviru parničnog postupka za naknadu štete. ${ }^{24}$ Kako smo se opredelili za stav da izvršilac predmetnog dela može biti na „poslodavačkoj” strani, potrebno je i da ga dodatno preciziramo. U tom smislu se treba osloniti na pojam „odgovorno lice” koji je definisan u domaćem KZ. Iako je u teoriji radnog prava razvijen stav da poslodavac poseduje normativnu, upravljačku i disciplinsku vlast, ${ }^{25}$ ne bi se moglo tvrditi da jedno lice može uspešno vršiti sva ta ovlašćenja u jednom većem sistemu. Zato se određeni poslovi poveravaju licima koja rade u okviru organizacije. U odnosu na složenost i odgovornost poslova, oni se grubo mogu podeliti na rukovodilačke i izvršilačke. Potencijalni izvršioci krivičnog dela iz čl. $163 \mathrm{KZ}$ mogu se tražiti među licima koja obavljaju prvu kategoriju poslova. Prema tome, nesporno je da pored poslodavca, izvršilac dela može biti i lice koje obavlja rad za njega, ali je važno da to zaposleno/radno angažovano lice obavlja poslove koji se mogu svrstati u rukovodilačke, budući da samo tako može doći u situaciju da odlučuje o nečijim radnim pravima i tako ih povredi.

Važno je istaći da izvršilac krivičnog dela iz čl. $163 \mathrm{KZ}$ ipak ne mora nužno da bude poslodavac ili lice koje kod njega obavlja poslove rukovođenja, pa čak ni lice koje se nalazi u istoj radnoj organizaciji kao i oštećeni. To se odnosi na povrede prava iz socijalnog osiguranja. Naime, teoretski je moguće da pravo na penziju bude povređeno onda kada zaposleni u Republičkom fondu za penzijsko i invalidsko osiguranje odbije da izda rešenje o penziji licu koje je na nju ostvarilo pravo, ne pridržavajući se svesno propisa iz socijalnog osiguranja uz umišljaj koji obuhvata uskraćivanje prava.

Kada je reč o posledici krivičnog dela, uskraćivanje u datom kontekstu predstavlja potpunu nemogućnost ostvarivanja prava, dok ograničavanje podrazumeva ostvarivanje prava u manjem obimu od predviđenog. Primera radi, u prvom slučaju bi se radilo o situaciji gde radniku nije uopšte rešenjem poslodavca određen godišnji odmor, pa on pod pretnjom otkaza, a češće jednostranog raskida ugovora,

22 O. Kahn-Freund: op. cit., p. 72.

23 Međutim, i danas je u pojedinim državama uočljiva tendencija predstavnika vlasti da u situacijama u kojima se u značajnoj meri povređuju radna prava i kada se očekuje reakcija države, posežu za argumentom da država ne može da se meša u privatne odnose na relaciji poslodavac - radnik, što je, kako smo videli, relikt ranijih vremena i pre ukazuje na neefikasnost državne intervencije kada je ona neophodna, no na želju nosilaca vlasti da se ne mešaju u privatne odnose. Tako je prethodni ministar za rad i socijalna pitanja u Vladi Republike Srbije izjavio da u slučaju sistemskog neisplaćivanja zarada država ne može ništa da učini za zaposlene, jer je to stvar njihovog internog odnosa sa poslodavcem, što je krajnje problematičan pristup. Vid. na: Đorđević: Nisam razgovarao s radnicima Goše jer je ta fabrika u privatnom vlasništvu, https://insajder.net/sr/sajt/ vazno/6495/, 20. mart 2021.

24 To ne utiče na krivičnu odgovornost radnika za krivična dela učinjena na radu i u vezi sa radom.

LJ. Kovačević /2013/: op. cit., p. 15. 
nastavlja da obavlja rad, ili mu nije isplaćena zarada u celosti, dok bi ograničavanje prava u našem primeru bilo određivanje manjeg broja radnih dana godišnjeg odmora ili isplata zarade u manjem delu.

\section{KRIMINALNO-POLITIČKI ASPEKT}

Radno i socijalno zakonodavstvo predviđa čitav niz prava, ali se postavlja pitanje da li se povredom svakog pojedinačnog ulazi u kriminalnu zonu koju predviđa čl. 163 KZ. Drugim rečima, potrebno je odgovoriti na pitanje koja to prava zaslužuju da budu zaštićena krivičnopravnim mehanizmom. Argument koji bi išao u prilog tezi da se odnosnom krivičnom normom pruža zaštita svim radnim i socijalnim pravima leži u striktnom jezičkom tumačenju i opštosti predmetnog krivičnog dela u pogledu objekta zaštite. Međutim, na taj način bi se doprinelo nepotrebnoj ekspanziji krivičnopravne reakcije i krivičnopravne materije uopšte, koja, istini za volju, biva podstrekivana aktuelnim modelom političke ekonomije ${ }^{26}$ kao i kaznenom populizmu koji otupljuje oštricu krivične reakcije. ${ }^{27}$

Čini se da krivičnopravna zaštita prava po osnovu rada i prava iz socijalnog osiguranja u Republici Srbiji nije pretrpela naročite izmene, iako je ona prošla kroz period tranzicije od socijalističkog ka demokratskom uređenju, ${ }^{28}$ pa bi to bilo očekivano. Štaviše, utisak je da je dekriminalizacijom krivičnog dela Neizvršenje odluke o vraćanju radnika na rad, krivična zaštita radnika u kvalitativnom i kvantitativnom smislu degradirana. Istini za volju, moguće je da se odbijanje poslodavca da vrati radnika na rad podvede pod krivično delo propisano čl. $340 \mathrm{KZ}$ Neizvršenje sudske odluke, s tim da se ta inkriminacija ne odnosi na rešenja inspektora rada o vraćanju na rad (odnosi se samo na sudsku odluku) i da st. 2. navedene norme predstavlja i fakultativni osnov za oslobađanje od kazne ako bi poslodavac u toku postupka izvršio pravnosnažnu odluku suda (bez obzira na dugotrajnu štetu koju trpi lice koje čeka da bude vraćeno). Pored toga, na taj način se šalje i poruka o zakonodavčevom tretiranju te povrede i rangiranju njene društvene štetnosti.

Neisplata zarade se u dosadašnjoj praksi pokazala kao česta i ozbiljna povreda prava radnika. Bez obzira na uočen problem u praksi, naš zakonodavac nije predvideo neisplatu zarade kao posebno krivično delo. Čini nam se da bi to bilo potrebno kako bi se poslodavcima koji često grubo zanemaruju svoju obavezu i time učestvuju u prouzrokovanju strukturalnog društvenog problema, u izgled stavio najveći stepen prinude - pokretanje krivičnopravnog mehanizma. ${ }^{29} \mathrm{Na}$ taj način bi se u okviru

26 J. W. Stuntz /2001/: The Pathological Politics of Criminal Law, Michigan Law Review, vol. 100, iss. 3, p. 2001.

27 O tome vid. kod: Đ. Ignjatović (2017). Kazneni populizam - in: Kaznena reakcija u Srbiji VII deo (Đ. Ignjatović, ed.), Beograd, pp. 11-32.

28 Ovim ne zalazimo u ocenu kvaliteta tranzicionih procesa koji su se odigravali u našoj zemlji, budući da bi to iziskivalo studiju daleko većeg obima no što je to primereno za jedan ovakav rad.

29 Kazneni zakon koji je na snazi u Republici Hrvatskoj u čl. 132. propisuje krivično delo Neisplata plaće. Krivični zakonik republike Srpske (Službeni glasnik Republike Srpske, br. 64/2017, 104/2018 - odluka US i 15/2021) sadrži interesantno nomotehničko rešenje gde je neisplata zarade explicite navedena u zakonskom opisu dela koje odgovara krivičnom delu iz čl. 163 domaćeg KZ-a. 
te inkriminacije, na normativnom planu mogla rešiti i brojna druga pitanja, kao što je odsustvo odgovornosti u slučaju da je neisplata zarade uzrokovana finansijskim poteškoćama kod poslodavca, što je kod nas stav koji je kreirala sudska praksa.

Odsustvo „sluha” domaćeg zakonodavca za promene u svetu rada i potrebe za usklađenom i efikasnom zaštitom radnih prava, odnosno unapređivanjem instrumenata zaštite, pokazuje i izostanak krivičnopravne zaštite uzbunjivača. Praktično gledano, uzbunjivač najpre štiti interese zajednice, koja zauzvrat predviđa mehanizme za njegovu zaštitu koju nastoji da mu pruži. ${ }^{30}$ Primera radi, u Hrvatskoj se pod krivičnim delom Povreda prava na rad podrazumeva upravo situacija u kojoj poslodavac otkazuje ugovor o radu radniku koji se u dobroj veri zbog opravdane sumnje u korupciju obratio ili podneo prijavu nadležnim organima. ${ }^{31}$ Iako su u Srbiji uzbunjivači, po pravilu ostajali bez posla pod sumnjivim okolnostima, to pitanje je ostalo primarno u domenu građanskog prava, a bez explicite krivičnopravne zaštite.

Razmatrajući domen primene čl. $163 \mathrm{KZ}$ iz ugla uporednog zakonodavstva, primećujemo da tu figuriraju tri rešenja: prvo, koje podrazumeva navođenje prava čija zaštita dolazi u obzir, drugo, koje koristi formulaciju „osnovna prava po osnovu rada" pri čemu se sistemskim tumačenjem radnopravnih propisa dolazi do odgovora na to pitanje, i treće, koje izdvaja sve povrede radnih prava koja zaslužuju krivičnopravnu zaštitu u posebna krivična dela, pri čemu se opšta zaštita prava po osnovu rada i iz socijalnog osiguranja uopšte i ne predviđa, već se ta prava koja su ostala izvan domena krivičnog mehanizma štite u drugim kaznenim (prekršajnom) ili građanskom postupku.

Istorijska analiza rešenja u našim ranijim krivičnim zakonicima pokazuje da su se prethodni zakonodavci odlučivali da u biće krivičnog dela povrede prava po osnovu rada i prava iz socijalnog osiguranja, unesu i koja su to prava kojima se pruža zaštita tom normom. Tako je u našem ranijem krivičnom zakonodavstvu u doba „Druge Jugoslavije” zakonodavac predvideo krivičnu sankciju za poslodavca koji se svesno ne pridržava pravila o zasnivanju i prestanku radnog odnosa, radnom vreme$n u$, godišnjem odmoru ili odsustvovanju, o ličnom dohotku ili drugim primanjima iz radnog odnosa, o zaštiti na radu žena, omladine i invalida ili o zabrani prekovremenog i noćnog rada, ${ }^{32}$ čime je jasno opredelio prava koja se mogu zaštiti ovom krivičnom normom. Isto rešenje utkano je i u Krivični zakonik Republike Srpske, pa je tako tamošnji zakonodavac predvideo kažnjavanje za svesno nepridržavanje propisa koji se odnose na zaključivanje ugovora o radu i prestanku radnog odnosa, plate $i$ druga primanja iz radnog odnosa, radno vreme, pauze, odmore, godišnje odmore, ili odsustva, zaštitu žena, omladine i lica sa invaliditetom, zaštitu radnica zbog trudnoće i roditeljstva, zaštitu starijih radnika, zabranu prekovremenog ili noćnog rada ili plaćanja propisane naknade. ${ }^{33}$ Kod ovakvih nomotehničkih rešenja se ne postavlja pitanje koja prava ulaze u okvir krivičnopravne zaštite.

30 A. Stevanović /2020/: Pojam i uloga uzbunjivanja u sprečavanju korupcije - in: Uloga društva u borbi protiv korupcije (J. Kostić, A. Stevanović, eds.), p. 106.

31 Vid. čl. 131 važećeg Kaznenog zakona RH.

32 D. Atanacković: op. cit., p. 217.

33 Vid. čl. 209, st. 1 Krivičnog zakonika Republike Srpske. 
U ranijem Krivičnom zakonu Socijalističke Republike Slovenije (KZ SRSI) postojalo je gotovo identično krivično delo kao i delo propisano čl. $163 \mathrm{KZ}$, sa tom razlikom što je u KZ SRSI ono nosilo naziv Kršenje osnovnih prava radnika. ${ }^{34} \mathrm{Na}$ osnovu ovakvog rešenja, oslanjajući se na naziv krivičnog dela „osnovna prava”, sistemskim tumačenjem radnopravnih propisa, pa i samog ustavnog teksta u delu u kojem reguliše pravo na rad, može se odrediti opseg prava kojima se pruža zaštita konkretnom inkriminacijom. Potrebno je utvrditi koja su to radna i socijalna prava predviđena kao osnovna u datoj jurisdikciji. Konačno, mogući su modeli u kojima ne postoji opšta krivična zaštita radnih i socijalnih prava, ${ }^{35}$ već je zakonodavac odabrao društveno najopasnije povrede tih prava i obezbedio im zaštitu sa najvećim stepenom prinude.

Krivično delo iz čl. $163 \mathrm{KZ}$ primer je „srednjeg” rešenja koje se ne može oceniti kao optimalno sa stanovišta principa krivičnog prava - lege stricta i lege certa. Na taj zaključak nas upućuje činjenica da se iz predmetne inkriminacije ne može sa sigurnošću utvrditi na koja se sve radna i socijalna prava ona odnosi. Nesporno je samo da se njome daje zaštita pravima iz okvira posebne zaštite na radu omladine, žena $i$ invalida. Kaznenim odredbama koje sadrži ZOR predviđena je prekršajna odgovornost za povrede prava koja predviđa taj Zakon. Paralelna kaznena reakcija na povrede prava po osnovu rada i prava iz socijalnog osiguranja, ne samo da bi doprinela neopravdanom ekspanzionizmu krivičnog prava koji je najbolje opisan tvrdnjom da „kada je kriminal sve, onda kriminal nije ništa”, ${ }^{36}$ već bi u pitanje dovela i primenu pravnog principa ne bis in idem. Otuda smatramo da je odgovarajućim tumačenjem normi potrebno pronaći ona prava kojima se razmatranom inkriminacijom opravdano pruža zaštita.

Sa tim ciljem pošli bismo od prava na rad i njegove sadržinske konceptualizacije iz Ustava $\mathrm{RS}^{37}$ prema kojoj svako ima pravo na poštovanje dostojanstva svoje ličnosti na radu, bezbedne i zdrave uslove rada, potrebnu zaštitu na radu, ograničeno radno vreme, dnevni i nedeljni odmor, plaćeni godišnji odmor, pravičnu naknadu za rad $i$ na pravnu zaštitu za slučaj prestanka radnog odnosa. Krivična zaštita poštovanja dostojanstva ličnosti na radu i zaštite bezbednosti i zdravlja na radu iscrpljena je u nekoliko posebnih krivičnih dela koja predviđa KZ. Tako je sistemom eliminacije ostalo da zaključimo da bi ograničeno radno vreme, dnevni $i$ nedeljni odmor, plaćeni godišnji odmor, pravo na pravičnu naknadu za rad i na pravnu zaštitu za slučaj prestanka radnog odnosa, trebalo da budu radna prava koja dolaze u obzir kada je reč o primeni norme iz člana $163 . \mathrm{KZ} .{ }^{38}$

34 D. Atanacković: op. cit., p. 225.

35 Vid. Kazneni zakona RH.

36 D. Simeunović /2001/: Privredni kriminal, „podzemlje i savremena država - in: Privredni kriminal i korupcija (D. Radovanović, Đ. Mihaljević, eds.), Institut za kriminološka i sociološka istraživanja, Beograd, p. 167.

37 Vid. čl. 60, st. 4 Ustava RS.

38 Zakon o radu takođe predviđa osnovna prava zaposlenih, gde se navodi da zaposleni ima pravo na odgovarajuću zaradu, bezbednost i zdravlje na radu, zdravstvenu zaštitu, zaštitu ličnog integriteta, dostojanstvo ličnosti i druga prava u slučaju bolesti, smanjenja ili gubitka radne sposobnosti $i$ starosti, materijalno obezbedenje za vreme privremene nezaposlenosti, kao i pravo na druge oblike zaštite, u skladu sa zakonom i opštim aktom, odnosno ugovorom o radu. 
Na potrebu za određivanjem osnovnih radnih prava, tj. njihovih povreda koje su društveno najopasnije, čime zaslužuju krivičnopravni zaštitu, upućuje nas i ultima ratio priroda krivičnog prava. Kako bi se ubuduće izbegli problemi u praksi prilikom kaznenog reagovanja na povrede radnih prava i kako bi se obezbedilo ujednačeno postupanje organa formalne socijalne kontrole, bilo bi poželjno da naš zakonodavac u narednim novelama KZ uzme u razmatranje unošenje „osnovnih” radnih prava u biće dela iz čl. $163 \mathrm{KZ}$ po uzoru na Krivični zakonik Republike Srpske ili da izmeni naziv krivičnog dela po uzoru na KZ SRSI, odnosno da dekriminalizuje opštu krivičnu zaštitu radnih i socijalnih prava po uzoru na Kazneni zakon Republike Hrvatske, s tim da bi u tom slučaju značajno morao proširiti krug posebnih krivičnih dela kojima se tim pravima daje zaštita (Neisplata zarade, Neizvršenje odluke o vraćanju na rad i tome slično).

To međutim i dalje neće rešiti problem dvostruke kažnjivosti povrede predmetnih prava, budući da i dalje postoje delikti koji se nalaze u preseku krugova, krivične i prekršajne reakcije. Uzmimo za primer neisplatu zarade. Prethodno smo odredili krug radnih prava čiji značaj opravdava krivičnopravnu zaštitu i konstatovali da se pravo na zaradu nalazi unutar njega. Sa druge strane, ZOR predviđa da će se kazniti za prekršaj poslodavac koji nije isplatio zaradu, odnosno minimalnu zaradu. ${ }^{39}$ Sudska praksa je zauzela stav, čini se sasvim opravdano, da razliku treba praviti na nivou oblika krivice. ${ }^{40}$ Za krivičnu odgovornost je neophodno da je učinilac postupao sa umišljajem (svesno se nije pridržavao relevantnih propisa) koji mora da obuhvati i posledicu krivičnog dela - uskraćivanje ili ograničavanje prava. Kada je reč o prekršajnoj odgovornosti za neisplatu zarade, ona se može utvrditi i u slučaju nehatnog postupanja, ${ }^{41}$ a ukoliko je učinilac postupao sa umišljajem, nije neophodno, a ni moguće da njime bude obuhvaćena i posledica dela, imajući u vidu da ona nije predviđena u biću prekršajnog dela neisplate zarade. Prema tome, konačno optiranje za krivično, odnosno prekršajno gonjenje, trebalo bi da bude vršeno uzimajući u obzir krivicu učinioca, čime zakonodavac krivičnom odgovornošću preti onim poslodavcima koji najgrublje zanemaruju svoje obaveze po osnovu rada.

\subsection{Pitanje primene principa ne bis in idem pri kaznenoj reakciji države na povrede prava po osnovu rada i prava iz socijalnog osiguranja}

Princip ne bis in idem oličen u zabrani dvostruke kažnjivosti predstavlja jednu od osnovnih vrednosti modernih krivičnopravnih sistema, a u sistem evropske zaštite ljudskih prava uveden je 1984. godine donošenjem Protokola br. 7 uz Evropsku konvenciju za zaštitu ljudskih prava i osnovnih sloboda. ${ }^{42}$ Domaći KZ sadrži kontroverznu odredbu koja odstupa od logike Evropskog suda za ljudska prava (u daljem tekstu: ESLJP). Naime, u kaznenom zakonodavstvu Republike Srbije aktue-

\footnotetext{
39 Vid. čl. 273, st. 1, tač. 2 ZOR.

40 Presuda VKS Kzz 340/2016 od 12.04.2016, presuda Višeg suda u Jagodini Kž1 281/15 do 06.11.2015. godine.

41 Vid. čl. 20, st. 1 Zakona o prekršajima (Službeni glasnik RS, br. 65/2013, 13/2016, 98/2016 - odluka US, 91/2019 i 91/2019 - dr. zakon).

42 G. P. Ilić /2017/: Načelo ne bis in idem u praksi Evropskog suda za ljudska prava, Strani pravni život, $\mathrm{n}^{\mathrm{o}} 3$, p. 22.
} 
lan je koncept višestruke kažnjivosti postavljen u čl. 63, st. 3 KZ, gde se zatvor ili novčana kazna koju je osuđeni platio za prekršaj ili privredni prestup, kao i kazna ili disciplinska mera lišenja slobode koju je izdržao zbog povrede vojne discipline, uračunava u kaznu izrečenu za krivično delo čija obeležja obuhvataju i obeležja prekršaja, privrednog prestupa, odnosno povrede vojne discipline. Ova odredba uređuje situaciju u kojoj je osoba prvo proglašena krivom i izrečena joj je kazna u prekršajnom postupku, a nakon toga je proglašena krivom i izrečena joj je kazna u krivičnom postupku. Pretpostavka je da opis prekršaja odgovara opisu krivičnog dela. U takvoj situaciji, prema izričitoj zakonskoj odredbi, ne primenjuje se načelo ne bis in idem. ${ }^{43}$

Suprotno polazištu domaćeg KZ, ESLJP je načelno zauzeo stav da nije moguće dvostruko kažnjavanje za dela u dva različita kazneno pravna postupka koja proizlaze iz istog činjeničnog osnova (idem). Upravo se utvrđivanje činjeničnog identiteta pokazuje kao najteži zadatak za sudije. U literaturi se navodi i postojanje dijalektičkog problema koji se ogleda u tome što „činjenice” određuju „pravnu kvalifikaciju” slučaja, ali sa druge strane, različite „pravne kvalifikacije” takođe uzrokuju selektivno opažanje ,činjenica”. ${ }^{4}$

Počev od slučaja Zolotukhin protiv Rusije, ${ }^{45}$ ESLJP ujednačava svoju praksu u pogledu određivanja činjeničnog identiteta dela, zabranjujući „gonjenje ili suđenje za drugo 'delo ' u meri u kojoj ono proizlazi iz identičnih činjenica ili činjenica koje su u suštini iste”. Interesantan je u ovom kontekstu i test „istog dokaza” koji se primenjuje u sudskoj praksi SAD, a koji se može koristi kao svojevrsno kontrolno pitanje pri utvrđivanju idem elementa. Naime, postavlja se pitanje da li različita pravna kvalifikacija, krivična i prekršajna, zahteva dokaz koji druga ne traži? Ukoliko je odgovor potvrdan, ne bi se radilo o povredi principa ne bis in idem. ${ }^{46}$

Polazeći od toga da su potvrđeni međunarodni ugovori i opšteprihvaćena pravila međunarodnog prava deo pravnog poretka Republike Srbije, te da zakoni i drugi opšti akti doneti u Republici Srbiji ne smeju biti u suprotnosti sa potvrđenim međunarodnim ugovorima i opšteprihvaćenim pravilima međunarodnog prava, zaključujemo da dvostruka kažnjivost za delikte koji se tiču povreda prava po osnovu rada i prava iz socijalnog osiguranja, ne bi trebalo da bude dozvoljena, bez obzira na kontroverznu odredbu domaćeg KZ. To naročito važi za krivične i prekršajne delikte koji u osnovi imaju identičan činjenični osnov. Primera radi, krivično delo svesnog nepridržavanja zakona prema kojem je isplata zarade pravo radnika sa posledicom uskraćivanja njegovih prava i prekršajno delo neisplate zarade, proističu iz istog životnog događaja - poslodavac radniku za obavljeni rad nije isplatio zaradu.

43 Odluka ESLJP u slučaju Milenković protiv Srbije predstavlja svojevrsnu opomenu Srbiji zbog dvostrukog suđenja u istoj stvari, D. Kolarić /2019/: Uticaj odluka Evropskog suda za ljudska prava i Evropskog suda pravde na nacionalni pravni poredak - in: Kaznena reakcija u Srbiji IX deo (Đ. Ignjatović, ed.), Beograd, p. 227.

44 B. Zupančič /2011/: Ne bis in idem (zabrana ponovnog suđenja za isto delo) la belle dame sans merci, Crimen, ${ }^{\circ}$ 2, p. 171.

45 Zolotukhin protiv Rusije, 14939/03 od 10.02.2009. godine.

46 Blockburger protiv Sjedinjenih Američkih Država, 284 U.S. 299 (1932). 
Od odluke ESLJP u slučaju Engel i drugi protiv Holandije, ${ }^{47}$ postojanje krivične stvari se procenjuje prema kvalifikaciji dela u domaćem pravu, prirodi protivpravnog ponašanja i vrsti i težini zaprećene kazne. Isključivo oslanjanje na činjenicu da je jedno delo predviđeno kao prekršaj, a drugo kao krivično delo, te se zato u konkretnom slučaju može konsekventno goniti za to delo, ne udovoljava kriterijumima ESLJP na osnovu kojih on utvrđuje povredu principa ne bis in idem, što je „na svojoj koži” osetila Hrvatska vlada u slučaju Tomasović protiv Hrvatske. ${ }^{48}$

Prema elaboriranom stanju stvari, domaći organi formalne socijalne kontrole trebalo bi da prave razliku između povreda radnih i socijalnih prava u pogledu toga da li će određenu radnju tretirati kao prekršaj ili krivično delo. Tačka razgraničenja trebalo bi da bude bezobzirnost poslodavca koja se ogleda u svesnom nepridržavanju propisa i postojanju umišljaja prema posledicama. Čini se da naši organi kaznenog gonjenja prečesto biraju „lakši put”, pa u najvećem broju slučajeva povrede radnih i socijalnih prava kvalifikuju kao prekršaje, pa čak i onda kada se, primera radi, isplata zarada zaposlenima ne vrši ni nakon višestrukih pisanih obraćanja poslodavcu koji posluje sa značajnim profitom. To svakako nije bila intencija zakonodavca. Olako pokretanje prekršajnih postupaka onemogućilo bi kasnije vođenje krivičnih, onda kada su za to ispunjeni svi uslovi. Najzad, na postojanje krivičnog dela, nije od uticaja da li je oštećeni pokrenuo radni spor, te kakav je njegov ishod. ${ }^{49}$

\section{ZAKLJUČNA RAZMATRANJA}

Imajući u vidu da većina ljudi na svetu svoju egzistenciju obezbeđuje radom, dok je obezbeđivanje sredstava za život rentiranjem kapitala „privilegija” malobrojnih, zaštita radnih i socijalnih prava se pokazuje kao jedan od najvažnijih segmenata državne intervencije. Iz suštinske nejednakosti strana u radnom odnosu proizlaze i česte zloupotrebe i povrede tih prava koju vrši „poslodavačka” strana. Zato je važno da zakonodavac pažljivo odabere ona prava čije učestale i masovne povrede mogu prouzrokovati teže, negativne, strukturalne poremećaje u društvu, i da im pruži odgovarajuću krivičnopravnu zaštitu.

Od odabira tih prava kojima se pruža zaštita krivičnopravnim mehanizmom zavisiće i kvalitet radnih odnosa u određenom društvu. Međutim, to per se nije dovoljno ukoliko izostane efikasna primena krivičnopravnih normi kojima su propisna krivična dela namenjena zaštiti prava po osnovu rada i prava iz socijalnog osiguranja. Efikasna primena norme je sa druge strane, moguća onda kada je ona formulisana na odgovarajući način, što je svojevrstan izazov kada se radi o propisivanju krivičnih dela blanketnog karaktera koja nisu poput onih „mala in se" isključivi predmet regulisanja krivičnog zakonodavstva. Razmatrano krivično delo je mesto susreta krivičnog i radno-socijalnog zakonodavstva, pa se u nedoumici uvek treba osloniti na ultima ratio prirodu krivičnog prava i specifičan cilj radnog prava kao samostalne grane prava. 
Zakonski opis krivičnog dela Povreda prava po osnovu rada i prava iz socijalnog osiguranja iz čl. $163 \mathrm{KZ}$ izraz je opravdane težnje zakonodavca da tim pravima obezbedi opštu a priori zaštitu. U nomotehničkom smislu, biće krivičnog dela nije predviđeno na optimalan način. Unapređenje zakonskog opisa moglo bi da ide u nekoliko pravaca. Najpre bi bilo neophodno jasnije opredeliti radna i socijalna prava kojima se pruža zaštita analiziranom inkriminacijom, posebno iz razloga što ih ima u velikom broju, pa bi krivičnopravno reagovanje na svaku njihovu povredu dovelo do otupljivanja oštrice kaznene reakcije, ali bi otvorilo i pitanje poštovanja principa ne bis in idem, s obzirom da su te povrede mahom predviđene i kao prekršaji. Pažljivo čitanje krivične odredbe nas upućuje na zaključak da je bezobzirnost potencijalnog izvršioca dela, koja se ogleda u svesnom nepridržavanju propisa i postojanju umišljaja prema posledicama, okolnost koja zahteva krivičnopravni progon, umesto pokretanja prekršajnog postupka koji podrazumeva manji stepen prinude. Valjalo bi izbeći i primenu „kvazi uslova kažnjivosti” u pogledu objektivne nemogućnosti za ostvarivanje prava, koja je u sudskoj praksi, usled fleksibilnog zakonskog opisa, postala opšte mesto.

\section{LITERATURA}

Atanacković D. /1981/: Krivično pravo - posebni deo, treće izdanje, Privredna štampa, Beograd. Bellace J. R. /2014/: Human Rights at Work: The Need for Definitional Coherence in the Glob Governance System, The International Journal of Comparative Labour Law and Industrial Relations, vol. $30, \mathrm{n}^{\mathrm{O}} 2$.

Husak D. /2008/: Overcriminalization - The Limits of the Criminal Law, Oxford University Press, New York.

Ignjatović Đ. /2017/: Kazneni populizam - in: Kaznena reakcija u Srbiji VII deo (Ignjatović Đ, ed.), Beograd.

Ilić G. P. /2017/: Načelo ne bis in idem u praksi Evropskog suda za ljudska prava, Strani pravni život, $\mathrm{n}^{\mathrm{O}} 3$.

Kahn-Freund O. /1972/: Labour and the Law, Stevens\&Sons, London.

Kolarić D. /2019/: Uticaj odluka Evropskog suda za ljudska prava i Evropskog suda pravde na nacionalni pravni poredak - in: Kaznena reakcija u Srbiji IX deo (Ignjatović Đ., ed.), Beograd.

Kovačević LJ. /2013/: Pravna subordinacija u radnom odnosu i njene granice, Pravni fakultet Univerziteta u Beogradu, Centar za izdavaštvo i informisanje, Beograd.

Kovačević LJ. /2016/: Valjani razlozi za otkaz ugovora o radu, Pravni fakultet Univerziteta u Beogradu, Centar za izdavaštvo i informisanje, Beograd.

Simeunović D. /2001/: Privredni kriminal, „podzemlje i savremena država - in: Privredni kriminal i korupcija (Radovanović D, Mihaljević Đ., eds.), Institut za kriminološka i sociološka istraživanja, Beograd.

Stevanović A. /2020/: Pojam i uloga uzbunjivanja u sprečavanju korupcije - in: Uloga društva u borbi protiv korupcije (Kostić J, Stevanović A, eds.).

Stojanović Z. /2016/: Garantivna funkcija krivičnog prava - in: Kaznena reakcija u Srbiji VI deo (Ignjatović Đ., ed.), Beograd.

Stojanović Z., Delić N. /2013/: Krivično pravo - posebni deo, Beograd. 
Stuntz J. W. /2001/: The Pathological Politics of Criminal Law, Michigan Law Review, vol. 100 , iss. 3 .

Summers W. C. /1976/: Individual protection against unjust dismissal: Time for a statute, Virginia Law Review, vol. 62.

Zupančič B. /2011/: Ne bis in idem (zabrana ponovnog suđenja za isto delo) la belle dame sans merci, Crimen $\mathrm{n}^{\mathrm{o}} 2$.

\section{ZAKONI I DRUGI IZVORI}

Kazneni zakon Republike Hrvatske, Narodne novine, br. 125/11, 144/12, 56/15, 61/15, 101/ 17, 118/18, 126/19.

Krivični zakonik Republike Srpske, Službeni glasnik Republike Srpske, br. 64/2017, 104/2018 - odluka US i 15/2021.

Ustav Republike Srbije, Službeni glasnik RS, br. 98/2006.

Zakon o prekršajima, Službeni glasnik RS, br. 65/2013, 13/2016, 98/2016 - odluka US, 91/2019 i 91/2019 - dr. zakon.

Zakon o radu, Službeni glasnik RS, br. 24/2005, 61/2005, 54/2009, 32/2013, 75/2014, 13/2017 - odluka US, 113/2017 i 95/2018 - autentično tumačenje.

Zakona o doprinosima za obavezno socijalno osiguranje (Službeni glasnik RS, br. 84/2004, 61/2005, 62/2006, 5/2009, 52/2011, 101/2011, 7/2012 - usklađeni din. izn., 8/2013 usklađeni din. izn., 47/2013, 108/2013, 6/2014 - usklađeni din. izn., 57/2014, 68/2014 dr. zakon, 5/2015 - usklađeni din. izn., 112/2015, 5/2016 - usklađeni din. izn., 7/2017 usklađeni din. izn., 113/2017, 7/2018 - usklađeni din. izn., 95/2018, 4/2019 - usklađeni din. izn., 86/2019, 5/2020 - usklađeni din. izn., 153/2020 i 6/2021 - usklađeni din. izn.).

Presuda OS u Beogradu Kž. 2275/96.

Presuda OS u Subotici Kž 411/07.

Presuda Prvog osnovnog suda u Beogradu P1 1463/19.

Presuda Višeg suda u Jagodini Kž1 281/15 do 06.11.2015. godine

Presuda Višeg suda u Užicu Kž 29/17 od 15.03.2017. godine.

Presuda VKS Kzz 340/2016 od 12.04.2016. godine

Blockburger v. U. S. 284 U.S. 299 (1932).

Engel i drugi protiv Holandije, 5100/71 od 8.06.1976. godine.

Lochner v. New York, 198 U.S. 45 (1905).

Tomasović protiv Hrvatske, 53785/09 od 18.10.2011. godine.

Zolotukhin protiv Rusije, 14939/03 od 10.02.2009. godine.

Đorđević: Nisam razgovarao s radnicima Goše jer je ta fabrika u privatnom vlasništvu https://insajder.net/sr/sajt/vazno/6495/, 20.03.2021. 


\title{
Aleksandar Stevanović*
}

Institute for Criminological and Sociological Research

\section{VIOLATION OF LABOUR RIGHTS AND SOCIAL SECURITY RIGHTS: THE PROBLEMS IN PRACTICE AND THE NEED FOR REVISION}

\begin{abstract}
SUMMARY
The aim of the paper is to determine the main characteristics of the crime in question. It was pointed out that this is a criminal norm that provides protection to labor relations in a general way, i.e. workers' rights. Therefore, there are numerous ambiguities in judical practice, mostly concerning the legal qualification of the violation of labor regulations and issues of proper application of the ne bis in idem principle. The paper specifically points to de lege ferenda legal solutions that would aim to more clearly determine the scope of labor rights that are protected by the relevant criminal norm.
\end{abstract}

Key words: labor, labor rights, ne bis in idem, criminal protection of workers.

\footnotetext{
* aleksandar.stevanovic993@gmail.com.
} 